\title{
Editorial
}

\section{Special Issue: Chinese Buddhism from Holmes Welch to the Present}

This special issue of Review of Religion in Chinese Society is devoted to an examination of the state of the field in scholarship on Chinese Buddhism since the death of Mao. It is based on a consultative meeting that was held at the Center on Religion and Chinese Society at Purdue University on April 28, 2018. The meeting featured a discussion among leading scholars in contemporary Chinese Buddhism whose revised work is presented in this issue.

Drawing on our discussions at the consultative meeting, the articles in this issue extend the legacy of Holmes Welch, whose three monographs on modern Chinese Buddhism (Welch 1967, 1968, 1972) broke new ground beyond the textual studies of the time to present a rich picture of Chinese Buddhism as a lived tradition in early to mid-twentieth century China. All of the contributors to this issue have undertaken extensive longitudinal studies of Buddhism in the post-Mao era and here combine their own findings with a critical discussion of the growing corpus of social scientific studies of contemporary Chinese Buddhism. Three of the contributors have published their own monographs on the topic (Fisher 2014; Borchert 2017; Caple 2019) while the other two have published seminal articles and edited volumes (Gildow 2014; Travagnin 2016, 2019).

Douglas Gildow begins the issue with a survey of developments in Han Chinese monasticism since the beginning of the post-Mao revival in the late 1970 . Drawing extensively from his own recent ethnographic research, Gildow questions the notion of a continuous revival of monastic institutions and lineages over the last forty years, suggesting instead that after an initial period of revival in the last two decades of the twentieth century, monasticism has plateaued and even may be now on the decline. Gareth Fisher's article complements Gildow's by discussing the evolution of the laity within Han Chinese 
Buddhism during the post-Mao period. His article also points to different stages in the evolution of post-Mao Chinese Buddhism, from an initial stage of the revival of devotional activities to more serious lay Buddhist engagements with Han Chinese Buddhist thought in the 1990s and 2000s, and finally to a resurgence of lay interest in meditation-based and Tibetan varieties of Buddhism in the 2000s and 2010s. Fisher's article observes how the laity is not always led by monastics but frequently engages in independent religious activities.

Jane Caple's article addresses the evolution of Tibetan varieties of Buddhism in the post-Mao period. Noting that most scholarship on Tibetan Buddhism focuses either on the revival of Buddhist traditions for Tibetans or Han Chinese engagement with Tibetan Buddhist teachings and masters, Caple's article synthesizes these two strands of scholarship together with her own work to show how both Han Chinese and ethnically Tibetan practitioners can be motivated by the anxieties of modernity to seek authentic forms of religious experience through Tibetan Buddhist persons, teachings, and institutions. Moving to Theravada Buddhism, Thomas Borchert's article explores how the Dai-lue of Sipsongpannā (Xishuangbanna 西双版纳) in Yunnan Province have negotiated with the post-Mao Chinese state to carve out a space for their own tradition. Focusing on three aspects of the rebuilding of the sangha-human capacity, educational capacity, and building monastic structures-Borchert argues that the post-Mao state's deployment of the category of religion, while aimed at regulating the social development of its minorities, paradoxically creates "zones of legitimacy" wherein the Dai-lue can achieve a degree of autonomy in cultural revival.

Finally, Stefania Travagnin's article considers the role of media and technology in post-Mao Chinese Buddhism. Focusing on the virtual robot monk Xian'er 贤二 at the Longquan 龙泉 Monastery in Beijing, Travagnin shows how quickly virtual technology has spread within Chinese Buddhism and how it can serve to facilitate the continued growth of the religion even in a period of increased regulation under the presidency of Xi Jinping. Travagnin's article situates Xian'er within a long tradition of media and virtual technology in global Buddhism and asks whether the range of Buddhist religious actors can be expanded to include artificial intelligence.

While presenting a review of Chinese Buddhist practice since the beginning of the post-Mao era, these articles also break new ground in scholarship on contemporary Buddhism in mainland China by critically reexamining existing assumptions concerning this dynamic and contingent religious field. This reexamination has three main aspects.

The first of these aspects is a challenging of conventional, often unexamined ideas concerning the ways in which scholars of post-Mao Chinese 
Buddhism - as well as post-Mao Chinese society more broadly — tend to periodize its history. As Gildow's article points out most explicitly, there is a tendency to treat Chinese Buddhism as undergoing an extended period of "revival" that extends from the beginning of reform in the Deng Xiaoping era to the present day, along with an (often implicit) tendency to treat the entire post-Mao period as though it were a single historical moment. Now, forty years into the Reform era, this type of treatment must be questioned. All of the contributors to this issue do so by pointing out the diverse phases of post-Mao Chinese Buddhism. Gildow's article does this most directly by arguing that treating the entire post-Mao era as a single period of revival obscures changing fortunes in monastic development during this time. Instead, Gildow proposes seeing the period from 1979 to approximately 2000 as a period of revival, when numbers of monastics and monastic institutions increased, which he contrasts with a period of "regulated development" from 2000 to the present, when those numbers have stagnated. Borchert's article also notes that, after an initial period of revival, the numbers of monastics in Sipsongpannā have declined. Fisher's article explores different phases of lay Buddhist growth within the postMao period. Caple's article complicates the notion of a Tibetan Buddhist revival of tradition by noting how a younger generation of Tibetans approaches Buddhism differently. Finally, Travagnin's article describes the influence on 2010s Buddhism of technological innovations that could not have been imagined in the 1980 or or 1990 .

The second of these aspects of reexamination is the complication of conceptual categories within the study of contemporary Chinese Buddhism (and perhaps Chinese religion more broadly) that aim to create analytical distinctions by classifying Buddhist persons in dyadic pairings such as monastic/lay, Tibetans/Chinese, and even human/machine. As Gildow's article points out, there are many different ways to define a monastic. Gildow's and Borchert's articles observe how, rather than being a definite category, monasticism, as well as the meaning of status labels given to individual monastics, can be quite fluid; moreover, the category of monastic is one in which the state is heavily invested and which therefore becomes quite political. Fisher's article complicates the notion of a sharp binary between monastics and lay practitioners. Critiquing the idea that lay practice is primarily devotional in nature, Fisher points out how laypersons, like monastics, engage actively in Buddhist religious practice rather than absorbing Buddhist teachings passively. Laypersons can also take on many of the functions of monastics, such as leading rituals, organizing study groups, and creating practice sites. Caple's article complicates the distinction between Tibetan practitioners of Tibetan varieties of Buddhism as authentic Buddhists concerned with the revival of cultural tradition, 
on the one hand, and Han Chinese practitioners of Tibetan varieties of Buddhism as consumer-oriented spiritual seekers on the other. Caple observes that Tibetan Buddhists themselves sometimes argue that certain Han Chinese practitioners exhibit authentic Buddhist practice through their sincere engagement with the core of Buddhist teachings. Conversely, many Tibetan Buddhists worry about the rise of materialism within their own traditions, echoing the concerns of those Han Chinese whose own interest in Tibetan Buddhism developed in reaction to the perceived corruption of Chinese Mahayana traditions. Both sets of practitioners can be motivated to use Buddhism to find spiritual authenticity amid the social and psychological uncertainties of modernity. Lastly, Travagnin's article calls into question the ways in which we see technology as merely a tool that human adherents of Buddhism can use on their own spiritual journeys. In many respects, synthetic beings like Xian'er can also count as practitioners in their own right.

The third of these aspects of reexamination concerns the changing role of the state. While scholars of religion in the first thirty years of the post-Mao period often contrast the Maoist state's repression of religion with the postMao state's co-option and control of religion, the rise to power of China's current president Xi Jinping has clearly changed the state's relationship to religion again, prompting journalist Ian Johnson (2019) to recently label the Xi period a third era "in the history of the Chinese communist party's religious policies." Several of the articles in this issue point to the absorption of the State Administration for Religious Affairs (SARA) into the United Front Department in early 2018 as a significant moment in the state's changing relationship to religion. This change placed the administration of religion more directly under the control of the state. While much attention has been given to the effects of this more direct control on the practice of Islam and Christianity, it has also had an effect on Buddhist practice in terms of, among other policies, stricter regulations on the registration of new temples and online Buddhist practices and less tolerance for Buddhist practice in sites not registered by the state as "religious activity centers" (zongjiao huodong changsuo 宗教活动场所). Borchert's and Travagnin's articles address the early effects of changing state policies, arguing that negotiation between Buddhist practitioners and the state is still feasible. Fisher's article argues that although the Xi state has exerted tighter control over Buddhist religious spaces, new technologies continue to facilitate the creation of new Buddhist groups. More research is needed to assess the longterm significance of the state's more direct control of Buddhism and other religions. The articles in this issue make a start toward addressing these changes. 


\section{References}

Borchert, Thomas. 2017. Educating Monks: Minority Buddhism on China's Southwest Border. Honolulu: University of Hawai'i Press.

Caple, Jane. 2019. Morality and Monastic Revival in Post-Mao Tibet. Honolulu: University of Hawai'i Press.

Fisher, Gareth. 2014. From Comrades to Bodhisattvas: Moral Dimensions of Lay Buddhist Practice in Contemporary China. Honolulu: University of Hawai'i Press.

Gildow, Douglas M. 2014. "The Chinese Buddhist Ritual Field: Common Public Rituals in PRC Monasteries Today." Journal of Chinese Buddhist Studies 27: 59-129.

Johnson, Ian. 2019. "China's New Civil Religion.” The New York Times. December 21. https://www.nytimes.com/2019/12/21/opinion/sunday/chinas-religion-xi.html (accessed December 23, 2019).

Travagnin, Stefania, ed. 2016. Religion and Media in China: Insights and Case Studies from the Mainland, Taiwan and Hong Kong. London: Routledge.

Travagnin, Stefania. 2019. "Cyber-activities and 'Civilized' Worship: Assessing Contexts and Modalities of Online Ritual Practices." In Buddhism after Mao, edited by Ji Zhe, Gareth Fisher, and André Laliberté, pp. 290-311. Honolulu: University of Hawai'i Press.

Welch, Holmes. 1967. The Practice of Chinese Buddhism: 1900-1950. Cambridge, MA: Harvard University Press.

Welch, Holmes. 1968. The Buddhist Revival in China. Cambridge, MA: Harvard University Press.

Welch, Holmes. 1972. Buddhism after Mao. Cambridge, MA: Harvard University Press.

\section{Gareth Fisher}

Syracuse University, Syracuse, NY

gfisher@syr.edu 